A

\title{
Reserkch Aвтіск: Constraints faced by Kharif sorghum growers in adoption of recommended technology
}

\author{
S.N. GHUGE AND R.P. KADAM
}

Article Chronicle: Received :

25.06.2015;

Revised :

30.09.2015;

Accepted :

13.10.2015

KeY Words :

Constraints, Sorghum and technology

Author for correspondence :

\section{R.P. KADAM}

Department of

Extension Education,

Vasantarao Naik

Marathwada Krishi

Vidyapeeth, PARBHANI

(M.S.) INDIA

Email: rpk.mkv@

gmail.com

See end of the article for

authors' affiliations

SUMMARY : The study was conducted in purposively selected three talukas viz., Kandhar, Mukhed and Loha of Nanded District of Marathawada region of Maharashtra state during the year 2014-15. From each taluka, four villages selected purposively and from each village 10 respondents were selected randomly, there by constituting a total sample size of 120 respondents and the constraints faced by Kharif sorghum growers in adoption of recommended technology were studied. The result of the study depicted that high cost of chemical fertilizer, high cost of tractor charges for tillage, non-availability seed at proper time, high cost of FYM, non-availability of labour at the time of harvesting, high cost of pesticide or insecticide, inadequate knowledge about scientific plant protection, inadequate knowledge about the proper NPK does, while the major suggestions offered by them were crop loan should be provided on time, improved seed should be provided in time and sufficient in quantity, cost of seeds, fertilizers and pesticides should be reduced, supply of inputs should be provided in time, provide the information about seed treatment and short duration and draught resistant varieties be developed.

How to cite this article : Ghuge, S.N. and Kadam, R.P. (2015). Constraints faced by Kharif sorghum growers in adoption of recommended technology. Agric. Update, 10(4): 312-317. 